\title{
Applications of Drone Technology in Construction Industry: A Study 2012-2021
}

\author{
Gayatri Mahajan
}

\begin{abstract}
Technology plays a pivotal role in shaping construction industry. Adoption of new trends, tools, software and technology would motivate to minimize problems that arise during use of drones in construction. The paper not only elaborates previous reviews on Drone Technology (DT) in Construction Industry (CI), but also explores extensive literature review on (i) classification of drones, construction software used with drone, (iii) overview of utility of $D T$ in construction and related industries (iv) recent construction technology trends, tools and techniques accomplish with drone technology. This is basically a review paper. The aim of this paper is to study the potential of DT in construction industry, extended it to understand the following issues in better way(i) benefits and impacts of drone in CI, (ii) record disadvantage of drone in CI(iii) integration of BIM with DT at substantial length and volume (iv)extensive description and enumeration on applications and uses of drones in CI(v) use of drone at each stage of construction stage to monitor the progress of construction rightly from the purchase of land to close out the project(vi)lastly appended a note on the impact of COVID-19 on construction. This study (2012-2021) also discusses challenges, opportunities, limitations, and strategies for the adoption of drones in construction. It assists to contractors, building planners, designers, academicians, engineers, and architects to improve the construction activities for greater efficiency and better performance. It also motivates towards inclusion of these technologies in the curriculum in Architecture Engineering.
\end{abstract}

Keywords: Drone technology, Unmanned Aerial Vehicle (UAV), Advance construction software, Construction technology trends, and construction stages, BIM integration

\section{INTRODUCTION}

The world is continuously deploying new technologies in Construction Industry (CI) for the speed, accuracy and safety in the construction projects. Advanced modern technologies are entering CI for the faster execution of projects. At the same time to cope-up with execution speed, monitoring methods are also getting modernized. Thus, the drones have come into picture; they do not contribute for the actual execution but make a huge contribution in faster monitoring of the projects which help in faster decisionmaking leading to lower the time lag in the projects too. Drones can be used right from the stage of land purchase till the post construction stage of the project They are used from pre-construction; construction to post-construction stage of the engagement of conventional methods for site survey,

Manuscript received on September 21, 2021.

Revised Manuscript received on October 23, 2021.

Manuscript published on October 30, 2021.

* Correspondence Author

Gayatri Mahajan*, Assistant Professor, Allana College of Architecture, Pune. (Maharashtra). India.

(C) The Authors. Published by Blue Eyes Intelligence Engineering and Sciences Publication (BEIESP). This is an open access article under the CC BY-NC-ND license (http://creativecommons.org/licenses/by-nc-nd/4.0/) contour mapping, site progress monitoring, construction quality management, etc. can be questionable, whereas drones can perform the same jobs with almost no risk and more accuracy and with lesser manpower too [1], [2].The construction process is classified into six stages, out of them pre-construction, construction and post-construction are important to consider entire project cycle [3].

The Indian CI is undergoing a seismic transformation, with technology playing pivotal role in shaping the industry [4],[5] [https://www. cecr.in,2021].The uses of drones are increased in the field of construction management in recent years [6]. Drones have become one of the compelling construction trends. In the next ten years, it is projected that the usage of drones in construction will rise, and they will play a key role in futuristic structures. The utilization of drones in the CI has a $239 \%$ development year-over -year world-wide, greater than any other commercial zone [7]. CI is one of the most unique, responsive and dynamic sectors in the Indian economy [8]. In India the growth is place to increase in the manifold. In the current situation, India must understand the aerial revolution that may be brought about by the correct use of drones, which have emerged as a highly viable economic instrument around the world. There is numerous safety and legal implications and user should be aware of the differences between the commercial and personal use of drones. All drones have to be FAA registered Despite growing usage and regulation, the use of drones in construction continues to develop rapidly[9].The introduction of drones is a positive development and will revolutionize the CI with great extent [10].

The monitoring of project progress with respect to the planning and scheduling is practically tedious and time consuming for site engineers as to keep real-time check on every corner of site and builders/contractors need to rely on these engineers for taking further decisions. The use of drones will be giving real-time progress on all parts of site and help contractors and other stakeholders to manage large number of sites by knowing proper data and taking necessary decision within less time, and also [11] has accounted 6 technologies disrupting the property and real estate industry. Drone technology is one of them. Drones help to spot potential risk and maintenance, to tour a property remotely, to survey properties and to create drawings as -built properties. Thus this paper includes review of existing literature on use of drones in construction industry/construction management/civil engineering to understand working and application in better way. This is first of its kind for 2021 for DT in CI.

\section{Published By:}

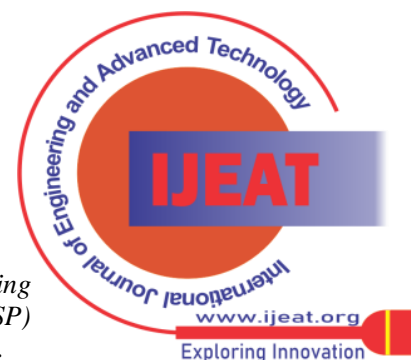




\section{BACKGROUND AND RATIONALE OF THE STUDY}

Construction is the second largest industry in India after agriculture. It generates huge employment in many ways. One serious problem is lack of manpower at working place. Engineers has been working hard to solve this problem. Use of modern technologies like IoT, automation, AI, CC, ML, BTC, BIM, 3D printing, robots, and drone/UAV can reduce load up to certain extent expecting with greater productivity and efficiency[12],[13],[14],[15],[16].Issues like security, risk assessment has to be considered equally. Better option among the above tools/ techniques/trends is adoption of DT/UAVs in construction to overcome effectively the problems raise for construction. The present article comprises a study on the following aspects: (2012-2021)

(ii) Accounting Use and applications of DT

(iii) Studies on benefits, impact, advantages and disadvantages, and BIM integration for DT

(iv) Elaboration of present study with challenges, opportunities and limitations

(v) Impact of pandemic COVID 19 on CI

Predominantly, the AEC industries are largely rewarding from the operation of drones [17].

UAVs save building projects both time and money. With their ability to collect real-time data at a job site, drones improve workflow and performance [17] in architectural engineering.

The main theme of the present article is to provide recent information about DT along with its uses and applications on the basis of studies conducted during 2012-2021. Hence present paper focus to know the working, role and implications of DT in CI, in Construction Management (CM), and Construction Project (CP), Construction Business (CB) in current scenario.

\section{LITERATURE REVIEW}

We have collected information from various resources especially from relevant references during a span of 10 years i.e., 2012 -2021 pertaining to drones' applications in CI. Few numbers of references are reported in the literature regarding use of drones/UAVs in construction by many authors [18], [19].

It is observed that a maximum number of articles appeared in literature, in last decade. [20] has briefly described the drone technology in AEC and provided guidance for UAV operation and implementation in the CI.[4][21] have extensively conducted a systematic literature review on the current topic pertaining to implementation of Unmanned Aerial System (UAS) in the CI covering the most relevant job, cases, and areas of application [21]. A critical literature review has been carryout out [22] on the relevant existing studies towards immersive and digital technologies. They analyzed the literature using meta-synthesis technique to (i) Extensive literature review research on DT/UAVs

evaluate and integrate the findings in a single context. UASs have rapidly been integrated into the CI over the past few years, and their application is continually growing in this domain. The recent developments in UAS regulations have played a significant role in their popularity and wide deployment in various stages of the construction lifecycle. A comprehensive study was conducted [23] in the United States to identify the practical construction UAS application areas, their adopted technologies, as well as the benefits and barriers encountered during their implementation. We have conducted extensive literature work on the following criteria to raise the recent literature and to understand use and applications. These are: (i) Concept of UAV and drone (ii) existing relevant reviews and literature on DT in CI (iii) types of drones and their uses (iv) construction drones software (v) overview of applications of drones in construction related industries(vi) construction stages, and drone applications(vii) benefits, impact, disadvantages, challenges and limitations of drones use in construction(viii) integration of BIM and drone uses (ix) CT trends and drones in CI, and (x) COVID 19 pandemic and its impact CI. The year-wise distribution of references is shown in Figure:1.

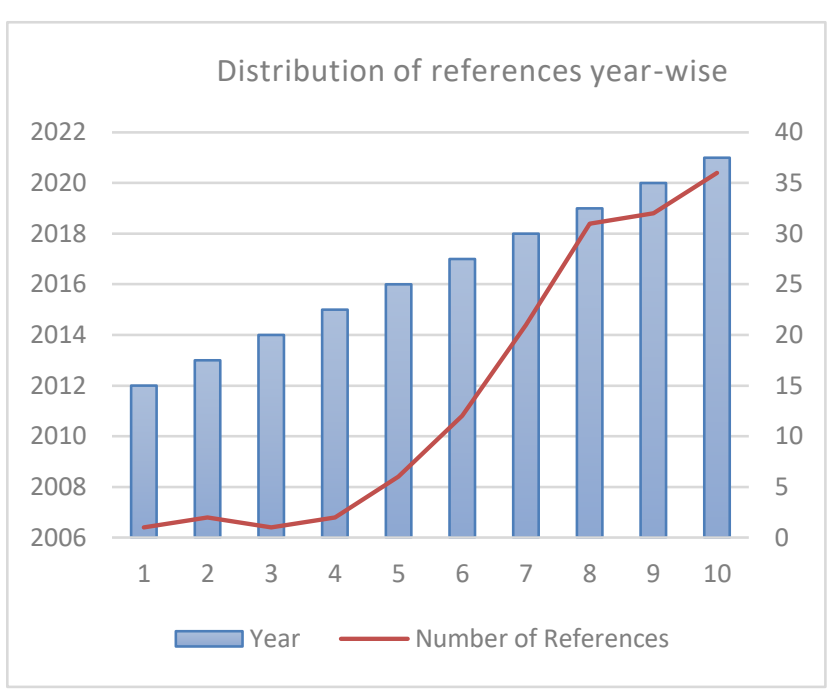

Figure 1: Year-wise distribution of references

\section{A. Detail about existing reviews on DT use in CI}

Drones provide construction companies with an outline of jobsites, materials, machinery and other concern people [14]. Contractors use the autonomous flying machines to note images and videos that help optimize everything from grading plans and operations to identifying differences between as-designed and as-built site plans.[14] People have started use of drones from 2012 in construction; thereafter various reports are available in literature on use of drones by reputed construction companies[14][17]. A number of existing reviews have been studied in the present context of the use of drones for construction for the period of 20122021(Table 1).Regarding DT use in CI various types of reviews are described here, such as general, systematic, critical, literature review, comprehensive review etc.

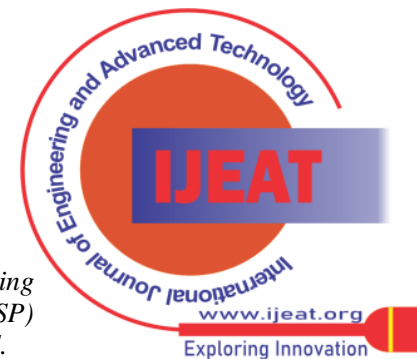


Table 1: Output of existing reviews studied on DT in CI (2012-2020)

\begin{tabular}{|c|l|c|c|}
\hline Sr. No. & Author, Date and Year & Reference Number & Applications \\
\hline 1 & F.Elghaish et al. Sept.9, 2020 & {$[22]$} & {$[24]$} \\
\hline 2 & Giusy Macrina, November ,2020 & {$[25]$} & 5 \\
\hline 3 & Javad Shahmoradi et al. 15 July,2020, & {$[26]$} & 3 \\
\hline 4 & RobinK. et al. March,2020 & {$[23]$} & 5 \\
\hline 5 & Gilles,A.Masoud,G.and Bryan,W.F.July,2019 & {$[27]$} & 7 \\
\hline 6 & Gaurav Singhal and Babankumar Shyam Bansod, November,2018 & {$[28]$} & 6 \\
\hline 7 & Shi Zhou and Masoud Gheisari October,2018 & {$[30]$} & 11 \\
\hline 8 & Soroush ,D. and Mahsa Asnafi,9 July 2018 & {$[31]$} & 6. \\
\hline 9 & M. Hassanalian and A. Abdelkefi .4 May,2017 & {$[32]$} & $14($ on the basis UAS) \\
\hline 10 & Peter Liu et al. April2014 & & 7 \\
\hline 11 & Gupta et al.April,2013 & & 7. \\
\hline
\end{tabular}

\section{B. Classification of construction drones and drones in construction}

Drones are designated by their performance, efficiency and technical characteristics such as weight, wing span wing load, highest altitude, speed, endurance, and production cost.

These are important parameters that distinguish different types of drones and provide useful classification system. [27] has categorized drones based on aerodynamics, on landing and weight and range. Furthermore, drones are classified based on their engine types[30].

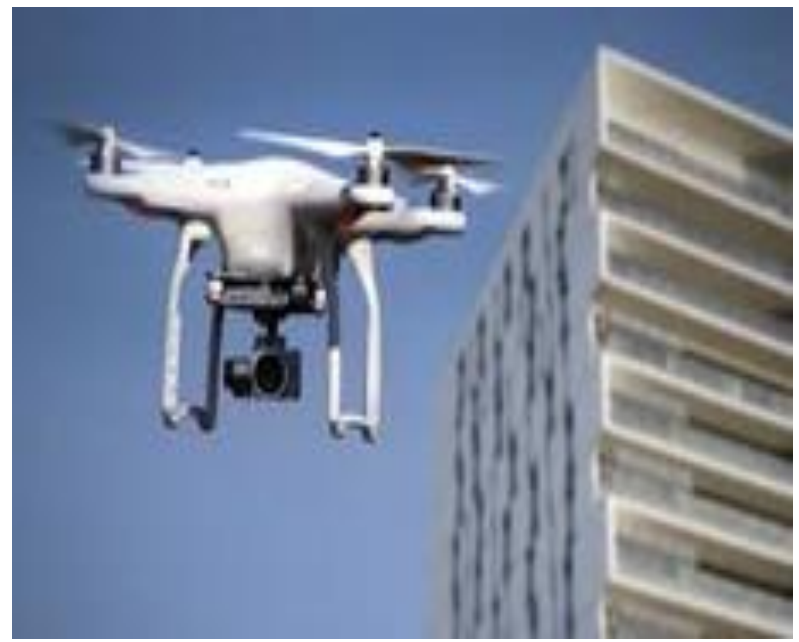

Figure 2 a; Drone in construction

and Figure 2b: shows two types of drones[28]. The general types of UASs are applied in construction are rotary-wing. Cameras, LiDAR and Kinect are the popular onboard sensors unified in construction.

[6] has classified drones as multirotor fixed-wing, single rotor and fixed-wing hybrid. Among these, multirotor drones like quadcopters have distinct advantages compared to other systems, such as robustness, high maneuverability and low purchase and maintenance cost. Multirotor drones have more than two and fixed-pitch blades.

In addition, UAVs hardware and software components are designed on the basis of their purpose and usage.[33] has provided detail information on UAVs use in construction along with applications and limitations.

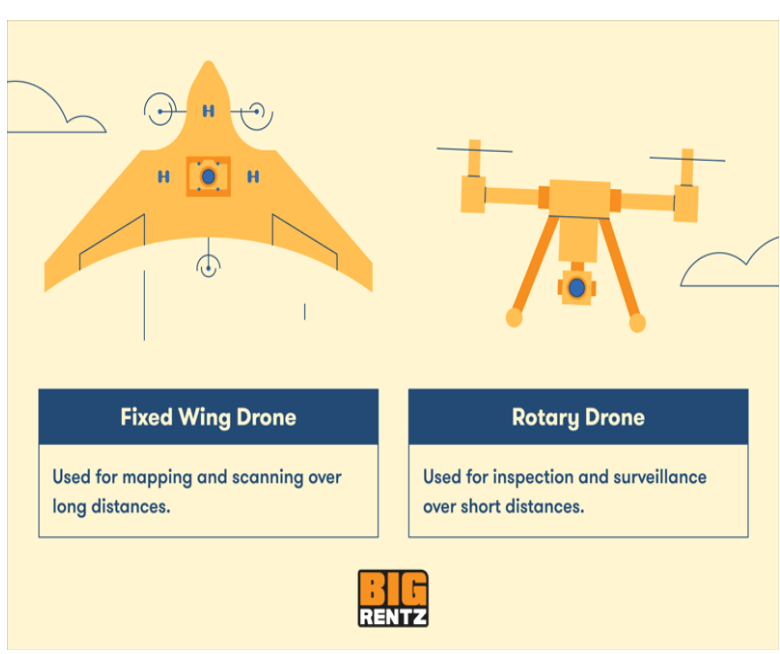

Figure2b: Types of Drones [source: 7]

[34] has classified drones on the basis of aerial platforms into best 4 major types: fixed wing drones, multi rotor drones, single rotor drones and fixed wing hybrid VTOL [Vertical takeoff and landing] drones. The first option for selection of drone is fixed type [35]. Drones are helping construction companies'. Use of them save money; improve safety conditions [7], [36].

\section{Use of Drone mapping software for construction}

Drones are versatile tools for safety and efficiently capturing imaginary and documenting progress at construction sites. Aerial drone maps help keep workers out of harm away and validate safety practices. UAV mapping can also provide control and budget when guiding subcontractors. A note for beginner's guide to drone mapping software is appeared in the literature where drone mapping use cases by industry, key mapping terminology and drone mapping software are precisely explained in such way that reader can understand fully [www.dronepilotgroundschool.com].Maps can be used to regularly update clients in the CI on the progress of their projects, analyzes stockpiles of raw materials such as dirt and gravel or even generate 3D models of construction sites.

\section{Published By:}

Blue Eyes Intelligence Engineering

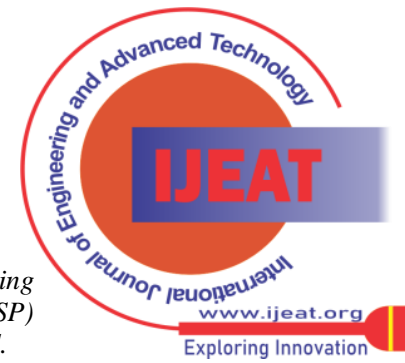


These maps can help construction managers to understand the "big picture" and support them in making strategic decisions. Drone mapping software can vary massively of cost and complexity Photogrammetry is the science of using images to map and measure distances, in short using photos to make measurements. With the help of photogrammetry software, we can process recorded information and generate digital models from it [www.dronepilotgroundschool.com]. Extensive information on drone mapping software is given in [36].Some of the most common applications areas of aerial photogrammetry includes construction, land surveying, real estate and agriculture [37]. He also recommended three photogrammetry software for drone pilots: (i) Pix4D : used in the real estate and renovation industries to generate photorealistic 3Dmodels of land and building. (ii)DroneDeploy:used in professional related to construction and agriculture, and (iii)Propeller PPK:a simple, powerful cloud software designed specifically for drone mapping, surveys and inspections within construction and material industries[36] and UAV photogrammetry software[37]. Recently,[38]has listed: True Veiw EVO by GeoCue ,Precision Mapper, MapsMdeEasy, Propeller and 3DF Zephyr in additional to previously mentioned software. Drone mapping software namely: Raptor Maps, Skycatvh, Drofica, Carlota, Micmac, COL MAP, Meshroom, Trible info and Webo DM for construction and other industries[37][38]. Very recently, [39] has summarized 5 top drone mapping software for the current year, namely (i) Agisoft Metashape (ii) DJI Terra: (iii) Global Mapper: (iv)Bentley Context Capture: (v)Pix4DMapper. Mapping such as re-planning, , identifying safety issues, tracing progress and recognizing potential problems / delays, creating 3D, and orthomosaic maps are most useful ways for use of drone in construction. Thus, the CI is greatly benefitting from done

\section{Utility of DT for CI}

Drones in construction allow contractors a chance to monitor any issue, track progress and develop better plans on-site by providing an unrivalled view of a site at a fraction of the cost. The use of drones in construction is a real flying industry. It's the wealth of practicality and readiness provided by drones which are actually building innovation and influence in the CI [www.safefacilities.co.uk], [40]. Table 2 vividly explains how drones and UAVs have directed the CI with different 9 categories such as construction and building, real estate marketing, public sector, visual inspection, solar panel inspection, monitoring road construction, railway inspection and monitoring, and transportation with application scale and narrated the clearly value of each category.

Table 2: Utility of Drone Technology (DT) for Construction Industries (CI)

\begin{tabular}{|c|c|c|c|c|}
\hline Sr. No. & $\begin{array}{c}\text { Industry } \\
\text { type/category }\end{array}$ & $\begin{array}{l}\text { Applicable } \\
\text { scale }\end{array}$ & Summation /utility & Reference \\
\hline 1 & $\begin{array}{l}\text { Construction site } \\
\text { monitoring using } \\
\text { UAV }\end{array}$ & construction & $\begin{array}{l}\text { Elaborated: i) UAV game-changer for CI } \\
\text { ii)various benefits UAVs in CI } \\
\text { iii|) construction site monitoring and planning } \\
\text { iv)micro aerial projects } \\
\text { v) improved decision -making process. }\end{array}$ & [41] [42] \\
\hline 2 & $\begin{array}{c}\text { Importance of } \\
\text { DT in real estate } \\
\text { marketing }\end{array}$ & $\begin{array}{l}\text { real estate } \\
\text { marketing }\end{array}$ & $\begin{array}{l}\text { Extended the importance of DT in CI; i) prerequisite of flying a drone } \\
\text { ii)rules and regulations by DGCA and FAA } \\
\text { iii)enumerated benefits DT in real- estate } \\
\text { iv|) recommended the future of drones in real- estate } \\
\text { v) real -estate photography }\end{array}$ & $\frac{\text { www.ifsec.events/ }}{\frac{\text { india }}{[43]}}$ \\
\hline 3 & $\begin{array}{l}\text { Significance of } \\
\text { drone in public } \\
\text { sector }\end{array}$ & public sector & $\begin{array}{l}\text { i)transport } \\
\text { ii) agriculture } \\
\text { iii)disaster Management } \\
\text { v)mining } \\
\text { vi)urban development } \\
\text { vi)traffic management } \\
\text { vii)homeland security } \\
\text { viii)oil and gas and Telecom }\end{array}$ & $\begin{array}{c}\text { www.equinoxdron } \\
\text { es.com,[9] } \\
{[44]}\end{array}$ \\
\hline 4 & $\begin{array}{l}\text { Visual inspection } \\
\text { across different } \\
\text { industries }\end{array}$ & $\begin{array}{c}\text { visual } \\
\text { inspection }\end{array}$ & $\begin{array}{l}\text { i)construction } \\
\text { ii) infrastructure and utilities } \\
\text { iii) benefits adopting drones for visual inspection } \\
\text { iv) time critical inspection operations } \\
\text { v) reduced cost of aerial inspection services } \\
\text { vii) value of AI -based visual inspection in2020. }\end{array}$ & [45] \\
\hline 5 & $\begin{array}{l}\text { Automate your } \\
\text { solar panel } \\
\text { inspection } \\
\text { using Ai- } \\
\text { powered drones }\end{array}$ & $\begin{array}{l}\text { solar panel } \\
\text { inspection } \\
\text { (Renewable } \\
\text { energy sector) }\end{array}$ & $\begin{array}{l}\text { i)Photovoltaic technology and photovoltaic effect } \\
\text { ii) comparison of manual Vs drone inspections (procedures) } \\
\text { iii)work out detection for solar panel defects } \\
\text { iv)thermal image of solar panel } \\
\text { v) drone inspection techniques and thermal infrared imagery }\end{array}$ & $\begin{array}{l}\text { www.equinoxdron } \\
\text { s.com }\end{array}$ \\
\hline 6 & $\begin{array}{l}\text { Road } \\
\text { construction and } \\
\text { monitoring using } \\
\text { drones }\end{array}$ & $\begin{array}{l}\text { monitoring road } \\
\text { construction }\end{array}$ & $\begin{array}{l}\text { i)road construction monitoring } \\
\text { ii) benefits using drones for road mapping } \\
\text { iii)highway infrastructure management } \\
\text { iv) post project documentation } \\
\text { v)bridge inspection } \\
\text { vi)pavement conditions and road distress monitoring } \\
\text { vii)corridor mapping deliverables for road mapping }\end{array}$ & $\begin{array}{c}{[46][47]} \\
\text { https://pigeonis.in. }\end{array}$ \\
\hline
\end{tabular}




\begin{tabular}{|c|c|c|c|c|}
\hline 7 & $\begin{array}{l}\text { Railway } \\
\text { inspection and } \\
\text { monitoring } \\
\text { using UAV/DT }\end{array}$ & $\begin{array}{l}\text { railway } \\
\text { inspection and } \\
\text { monitoring }\end{array}$ & $\begin{array}{l}\text { i)rail track monitoring through drone imagery (defect detection, crack } \\
\text { detections) } \\
\text { ii) camera-based image processing } \\
\text { iii)aerial inspection } \\
\text { iv)Increased safety for railway personnel in the inspection of assets in } \\
\text { remote or dangerous locations. }\end{array}$ & [23] [48] \\
\hline 9 & $\begin{array}{l}\text { Utility of drones } \\
\text { in transportation } \\
\text { and planning }\end{array}$ & transportation & $\begin{array}{l}\text { i)drones able to create new photos } \\
\text { ii)ICT tool for data collection } \\
\text { iiI) revolutionizing in transportation } \\
\text { iv)cargo drones: the future of parcel delivery }\end{array}$ & $\begin{array}{l}{[24][30]} \\
{[49]} \\
{[50]} \\
{[51]}\end{array}$ \\
\hline
\end{tabular}

With massive development and current technological advancement, the application of UAVs proceeds to remodel various industries and related areas. Planners and architects often employ drones as a real-time tool to observe their progress eventually in multiple domains. The usage of drones in business operations has broadened in different industries [52],[www.equinoxsdrones.com].The trend and order of literature sources studied are from webs, followed by journals, blogs, conference papers, survey reports, books during 2012-2021and these sources are used for synthesis of this article. Along with trends, references of DT in CI could rise at the end of 2021 and expected value may reach 40\% more.

\section{IV.MAJOR STUDY ASPECTS: POTENTIALS OF DT IN CI}

The last few decades UAVs or Drones have become relevant in the Construction industry and Civil Engineering [14] [34].In this decade many authors have described the potential applications of in the Construction and Engineering [23].[34],[53],[54],[100],[120].The use of drones/UAVSs is included in the list of recent construction technology trends [55]. Their use is higher than any commercial zone [https://content.sciendo.com].This section provides a detail account on various prospects of DT in CI with a appropriate citation of each in general along with the specific applications in particular.

\section{A. DT Technology in various stages of construction}

Drones have helped make several improvements in construction, from increased accuracy in reporting, to improving safety conditions, to cutting costs and increasing efficiency. Construction stages [1] namely pre-construction stage, construction stage, post-construction stage, and (iv) safety and maintenance are describes in the literature.[6] has extensively work out on done based construction management, construction planning land surveying, on site management and safety management for construction. In literature 5 phases for construction project are given :(i) planning and design, (ii)constructs/bidding, (iii), procurement. (iv) Construction, and (v) close out.[56],[www.dronebros.com]. A study conducted by [57] has suggested both positive and negative aspects of the use of the drones for structural inspection, underlying cost, immediacy, instant measurement and possibility of developing 3D model. [34] has pointed some requirements for pre-construction land surveying, mapping ,site inspection, trapping ,progress report, aerial photography, thermal imaging recording etc. These statements are well supported [Table3] by authors [58], [59]. Four stages namely:(i) design phase, (ii)operational phase, (iii)facility phase management and (iv)dismantling phase are described[https:biblus.accasoftware.com] .However, six stages namely:(i) project deliver phase (ii) pre-design phase, (iii) design phase, (iv)pre-construction phase ,(v) construction phase ,(vi) post construction phase are outline in chapter 1 which appeared in an article "An overview of delivery process" [www.pearsonhigheted.com].Recently, [2] has reinforced construction for 2020 which include 3 stages namely: past, present, and future of drones in construction. In the same year, [60]has proposed three ways:(i)remote pre-construction inspections(ii)real-time construction site monitoring, and (iii)low-risk structural maintenance for improving safety and efficiency at construction site using drone Very recently,[3]has classified the construction process primarily into six stages, as follows(:i)project conception, design, and planning (ii)building permits,(iii)pre-construction,(iv)procurement (v)construction, and(vi)post-construction. The construction industry is on the verge of a transformation. However,[61] has directed for use of survey drones and updated the construction process with implementation of survey drones in :(i) pre-construction,(ii) the construction phase, (iii) postconstruction phases, and (iv) drones and remote monitoring). Table 3 shows description of mainly four stages and their potential in detail.

Table 3: Details of various construction stages along with their activities.

\begin{tabular}{|c|c|c|c|}
\hline \multicolumn{4}{|c|}{ Construction Stages } \\
\hline & Stage & Action Taken & Reference \\
\hline \multirow{7}{*}{ 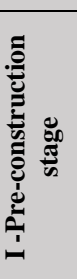 } & \multirow{3}{*}{ Planning } & (i) Site Selection & \multirow{3}{*}[1]{$[62][63]$} \\
\hline & & (ii)Topographic maps & \\
\hline & & (iii)Zoning & \\
\hline & \multirow{4}{*}{$\begin{array}{l}\text { Property Purchase \& } \\
\text { decision making }\end{array}$} & (i) Site location & \multirow{4}{*}[36]{$[64][65][66][67]$} \\
\hline & & (ii)Surrounding & \\
\hline & & $\begin{array}{l}\text { (iii)Site barriers } \\
\text { (iv)Aerial images \& videos }\end{array}$ & \\
\hline & & (v)decision on purchase & \\
\hline
\end{tabular}

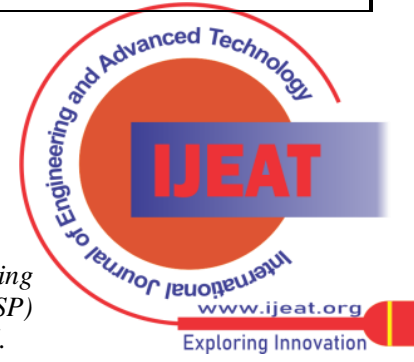


Applications of Drone Technology in Construction Industry: A Study 2012-2021

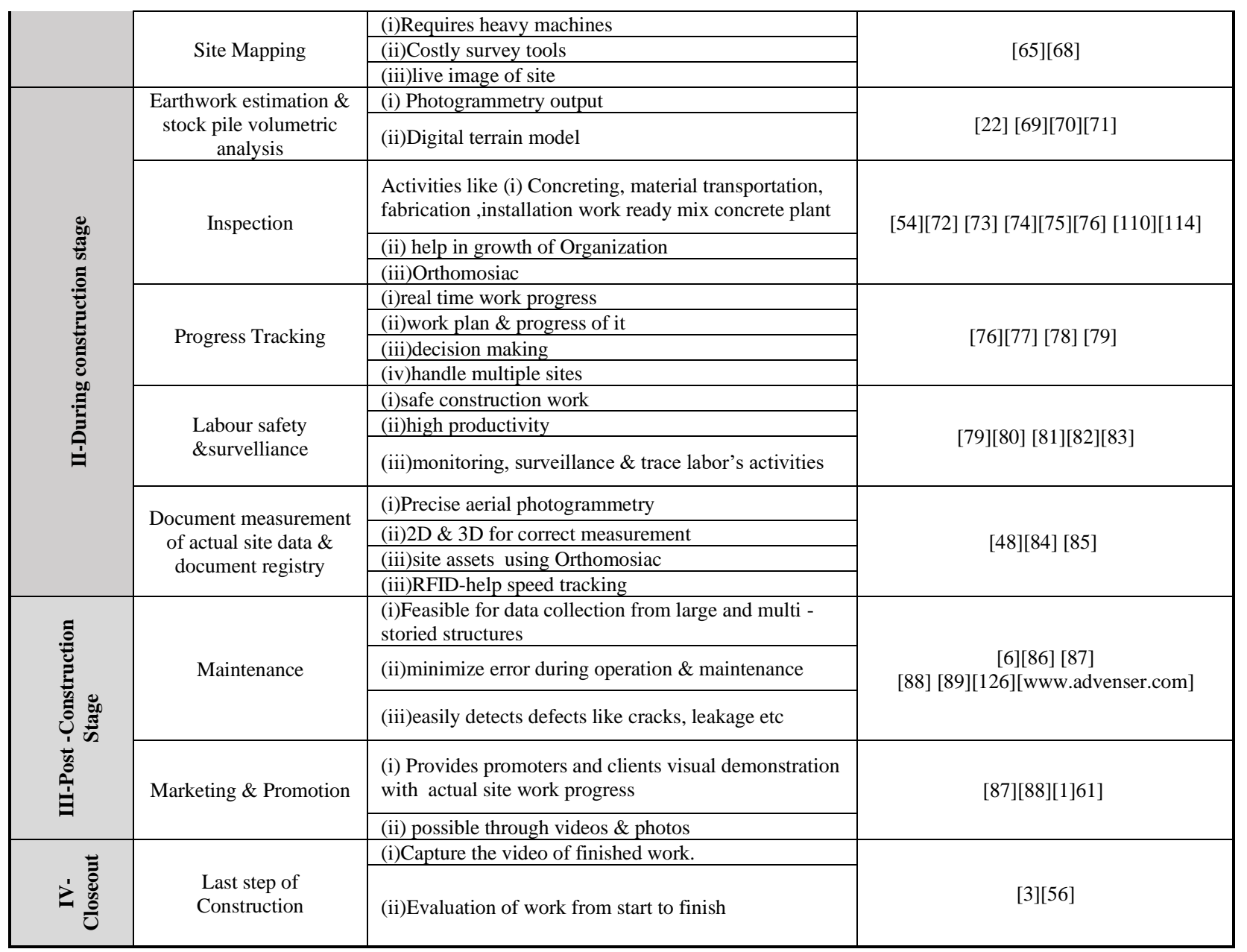

\section{B. Benefits of drone in construction}

The popularity in use of drones in construction industry is increasing steadily and provide a bird's eye view of a site at a relatively low cost of the construction They are relatively cheaper than flying manned aircraft. Construction companies believe that drones generate better working environment for employees. Current UAS uses within the CI generally fit into some important categories namely photography/videography, surveying, inspections, safety/security monitoring, 3D rendering services, accurate mapping[90],more accurate bids during pre-construction stage, inspection, safety, digital photography and documentation[91],[92].Drones with smart sensors, inspection, communication and logistics enhancement, reduce safety risks, structural integrity maintenance [89][93].Drones UAVs are no longer just considered high- tech toys. [94] has explored many benefits of unmanned aerial vehicles or UAVs for the CI. The benefits of these innovations are particularly common in construction. Traditional terrain surveys require manual acquisition of multiple GPS points. Depending on the size of the area, these points can easily contain hundreds of points. The drone accelerates this process. As drones are increasingly integrated into construction projects, they can also help improve accountability in the development process [95]. Since the drone can monitor the location every day, it can provide various documents for reference to prevent errors. This precise activity tracking can help monitor and prevent potential risks. We have selected and considered 13 articles [Table 4] based on studies on benefits of drones in construction industry.

Table 4: Practical benefits of drones in construction

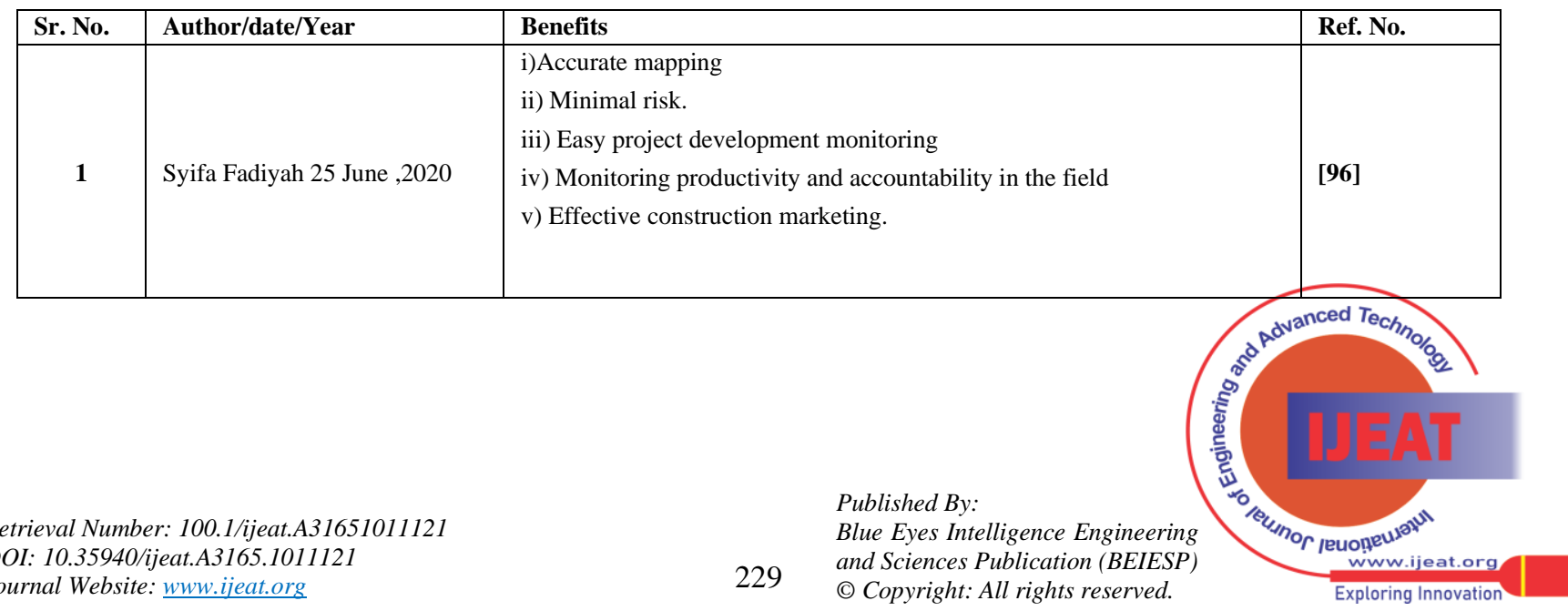




\begin{tabular}{|c|c|c|c|}
\hline 2 & Bhagwati Pathak.27 May 2019 & $\begin{array}{l}\text { i)saving time } \\
\text { ii) material inventory, stockpile volume, length, width and elevation for } \\
\text { structure and roads } \\
\text { iii) easily produce image and map } \\
\text { iv)| 3D Rendering Services }\end{array}$ & [97] \\
\hline 3 & $\begin{array}{ll}\text { Constro } & \text { Facilitator } \\
\text { Dec,21,2019 } & \end{array}$ & $\begin{array}{l}\text { i)environmental and economic advantage of drone in construction } \\
\text { ii) high-definition images mapping construction and modeling } \\
\text { construction projects., iii) allowing better iteration, higher feasibility and } \\
\text { iv) more accurate bids during the pre-construction phase. }\end{array}$ & [52] \\
\hline 4 & $\begin{array}{l}\text { Kumar Wiratunga January } \\
29,2019\end{array}$ & $\begin{array}{l}\text { i) mapping measurements, } \\
\text { ii)reduce safety risks } \\
\text { iii cost-effective } \\
\text { iv)efficient practical method to monitor construction process } \\
\text { v) improved communication }\end{array}$ & [90] \\
\hline 5 & Mukesh Sharma Sepe.29.2019 & $\begin{array}{l}\text { i) low costs and increase productivity } \\
\text { ii) opportunity to create new jobs and add value to the construction sector. } \\
\text { iii) can Fly ant where } \\
\text { iv)real-time information, accuracy in surveying } \\
\text { v) insurance cost of drones is low compared to on-site workers. } \\
\text { vii) construction site inspection within } 15 \text { minutes. } \\
\text { viii) improvements in photographic visualization }\end{array}$ & [91] \\
\hline 6 & Olivia Catterall 23 Sept. 2019 & $\begin{array}{l}\text { Benefits } \\
\text { i)safety and work flow surveys } \\
\text { ii)digital photography and record } \\
\text { iii)monitoring environmental factors } \\
\text { iv)improve worker safety } \\
\text { Risks:the need of Insurance }\end{array}$ & [92] \\
\hline 7 & Juan Rodriguez May 11,2018 & $\begin{array}{l}\text { i)Surveying application of drones } \\
\text { ii)safety inspection } \\
\text { iii)drones for structural and elemental inspectional, maintenance and } \\
\text { insurance } \\
\text { v)communication and logistics enhanced }\end{array}$ & [93] \\
\hline 8 & Mike Daniel,Feb.14,2018 & $\begin{array}{l}\text { i) Growing jobsite: application use cases for drones construction site, } \\
\text { include time lapse, forward looking in infrared, thermal imaging } \\
\text { ii) Boosting business development and marketing efforts: improve safety, } \\
\text { project efficiency } \\
\text { iii) data accuracy, capture the aerial perspectives achieve unusual angles, } \\
\text { marketing side -aerial } \\
\text { Photograph, video marketing for residential and commercial real-estate. }\end{array}$ & [98] \\
\hline 9 & McCabe et al,13 June 2017 & $\begin{array}{l}\text { i)Benefits: indoor domain include in-flight quickness, scope to hold an } \\
\text { assembling of sensors and automation potential } \\
\text { ii)Challenges: safety risks, battery capacity limits }\end{array}$ & [99] \\
\hline 10 & Quentin F.M.Dupont et al,2017 & $\begin{array}{l}\text { Analyzed in greater depth: :i)self-governing indoor flight for a UAV and } \\
\text { ii)implementation of collected data into the live BIM software }\end{array}$ & {$[100]$} \\
\hline 11 & $\begin{array}{l}\text { PaeNatwilai } \\
\text { https://dronenodes.com }\end{array}$ & $\begin{array}{l}\text { i)data capturing process, } \\
\text {, ii)better working environment for employees, planning and analysis } \\
\text { process, } \\
\text { iii)budget -friendly and faster }\end{array}$ & [101] \\
\hline 12 & Wingtra (Online) wingtra.com & Fast, reproducible, on-demand image acquisition & [85] \\
\hline 13 & steelcityflightacademy.com & $\begin{array}{l}\text { i)Data collection, land surveying, better project update, security and } \\
\text { surveillance, improve collaboration, } \\
\text { ii) Mitigate risk and increase security, waste management and } \\
\text { transportation. }\end{array}$ & \\
\hline
\end{tabular}

\section{Disadvantages of drone use in construction industry}

Essentially, a drone is flying robot obviously it has disadvantage. Three types of drones are in industrial practice. Single rotors are harder to fly than multi-rotor drone types. They have higher complexity. Fixed wings are expensive, expert person is required to fly [102]. Multirotors have a limited flying time. They only have small payload capabilities and have 15-30 minutes flying time. Following are disadvantages associated with drones are short flight time, easily affected by weather, drones warless problems, precise operation difficult. Strict and dangerous laws for the use of drones can cause serious harm, drone collision with people, collision with buildings criminal use [103].On the other hand, drones use have following advantages of using a drone for construction are: They can save lives, save time and cost of construction, provide safe infrastructure maintenance and management [104] and other industries [Table 2] also.

\section{DT impact on the CI}

Construction Industries need adoption of DT for construction projects for cost reduction and speed of work with minimum risk. As seen in previous section [Table 3] drone could provide value at every step in the building process. [105] published a report on "The impact of emerging technologies on the CI". And he emphasized on the adoption of new emerging trends in construction. In this report further he stated that the demand of drones will increase many fold by 2025.

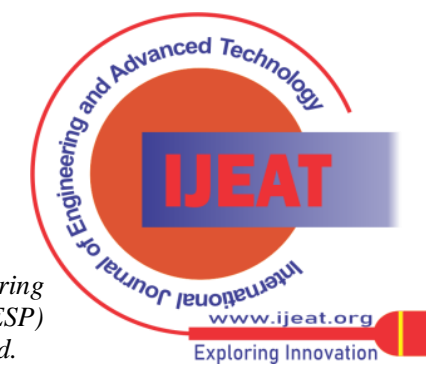


Drones offer big opportunities in the many areas of construction. The impact of emerging technologies on the value of construction project is given by [106] in his research project report. She describes various emerging construction technologies including adoption of $3 \mathrm{D}$ printing, AI, AR/VR mixed reality, BIM, mobile technology, robotics and drones.[https://ukconnect.com]. Construction projects that involve data collection, land surveying, big roads, and earthwork have been proven to be positively impacted by DT [https://www.thomastractor.com]. Table 5 summarizes a number of impacts quoted by various authors during 20122021 Drones are poised to cut the time it takes to build a skyscraper by a broad margin. During the study conducted [107] on the impact drone technology on the CI, he quoted three points: i) evolution is not revolution ii) drones have revolutionized, and iii) benefits of newer technology. [108] has summarized the impact of drones on CI with three issues namely: (i) allow contactors a chance to monitor any issue, track progress,(ii)deploying labor, material waste,(iii) essential and valuable documentation. It is seen from the literature various valuable issues like:(i)enabling more efficient construction site monitoring,(ii) width, length, and elevation for structures and roads,(ii) maps and images for easier communication, and (iv) material types and stockpile volume[https://www.procrewschedule.com],[www.thomsont ractor.com].Some trends having potential for the impact on project management and construction management are noted.[97][www.c-maanet.org,2016].These are:(i)tracking job progress(ii|) logistics and production planning (iii)inspection of areas difficult or impossible to access(iv)safety monitoring and support , and (iv)land surveying, thermal imaging, laser scanning. The future of drones in construction is growing and as UAVs technology increases, the need for drones in this industry will also continue to increase.

\section{E. Applications of DT in CI}

Builders use drones to collect real-time data about projects and understand what's happening on site. Aerial insights improve progress tracking and help to catch problems early-before they become costly. Below is the comprehensive description of applications of drone in CI progressively stating from 2012 to 2021 . In the recent years the UAVs have been greatly used for different construction and operation applications of various types of construction [30].Construction is an outdoor activity; maximum of the work is captured indoors. The indoor surrounding exists various challenges for automatic capture of data during progress monitoring, quality control, and quantity verification [28]. [29] has compiled and summarized data in the form of table along with 21 references /authors with applications obtained during 2011 to 2018. They have stated 3D modeling, damages assessment, surveying, safe monitoring, and project progress control. Drones or UAVs also eminent as a non-pilot craft has change the image of a war weapon to a construction equipment and has grown a warm market in CI recently by utilizing drones in different ways for construction projects [35].Furthermore she states that drone has attenuated hard tasks of project managers, technology managers, and superintendents by mitigating the risks and solving the main problems as; safety on site, rising project costs, lack of communication in a construction project. She also included information with features of drones, types of drones, construction software used with drone challenges such as, rules and regulations pilot licensing, trained operators lack of IT infrastructure. The drones have recently turned the attention in the architecture, engineering, construction, and operations (AECO) industry [109].Application of drones in construction project, UAVs system for construction safety, and implementing drone technologies in construction management/construction industry are summarized extensively[110],[111],[112].

It is possible to develop CI on acquiring recent innovative technologies. Such technologies can help in reducing the time needed to accomplish tasks, increase work quality, develop safety standards, and reduce expenses. UASs have various applications on construction sites [113].He had scrutinized 33 articles from the available articles (up to 2017) for the applications and issues in UAS use in CI. Moreover, he separated (partitioned) them into nine identified applications and ten issues for UAS in the CI as he has taken feedback from past 25 and 21 references, respectively. The findings have enhanced understanding of the implementation of UAS in CI. We have already seen that they are used to develop plans, track progress and monitor any issues throughout the construction process and provide an up-to-date aerial view of a construction site [114].This is also true in case of civil engineering [115]. Construction monitoring with the help of different steps is well defined using drone/UAV [116]. Drones used as effective tools to survey and map the landscape and multiUAVs useful for construction management [117]. [118] have provided a comprehensive review of efforts related to UAV development with a focus on civil infrastructure implementation. They offered and delivered relevant advance study such as :(i) delivered an instructions for researchers incorporation of UAVs into their research plan(ii) compared the advantages and disadvantages between different UAV types and also proved UAVs performance characteristics (iii) elaborated examples of different sensor payloads that demonstrate expanded functionality, and(iv) given an overview of research endeavors in the rising space of remote sensor networks and data processing algorithms specific to UAV -gathered data. The uses of drones in construction enlarge conclusively in recent years. Some of top uses of drones are listed [www.designinbuildings.co.uk].[119] [120] has suggested that the current challenges for application of UAV within CI and generally categorized into three areas: (i) the legal and regulatory requirements, (ii) the features and abilities of the UAVs, and (iii) the qualities and capabilities of the data capturing, processing, and presentation software. Their findings also indicated that the limitations of commercially available UAVs include restricted operation in adverse weather conditions, the inability to autonomously navigate dynamic environments, and inadequate weight capacity.

Published By:

Blue Eyes Intelligence Engineering

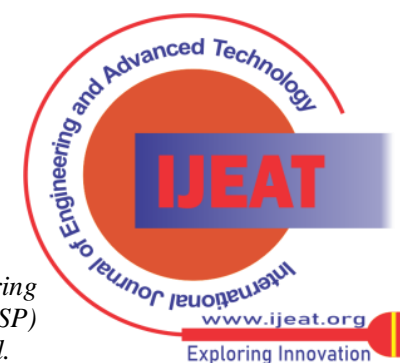


Andrew[121] in his thesis about 9 drone applications are mentioned Recently,[122]has introduced about some wonderful applications of drones that can help us to know about their impressive capabilities and out of applications studied, four are related to construction. Very recently, [123] in this report the author has extensively reviewed future of
CI considering pandemic of covid-19 and its implications on construction projects and risk management. Considering literature and recent data available it is easy to capture the knowledge of use and applications of drones in construction as evidently seen in [Table 5] given below.

Table 5: Applications and uses of DT in CI and CE

\begin{tabular}{|c|c|c|c|}
\hline Sr. No. & Author, Date \&year & Applications/uses & Ref. \\
\hline 1 & $\begin{array}{l}\text { Liza Brown } \\
\text { Feb.5,2021 }\end{array}$ & $\begin{array}{l}\text { i)in aerial photography } \\
\text { ii)in rescue operations } \\
\text { iii)in the field of agriculture } \\
\text { iv) for shipping and delivery } \\
\text { v)engineering applications } \\
\text { vi)3D with drones } \\
\text { vii)for safety surveillance } \\
\text { viii) wireless internet access } \\
\text { ix)in the field of research and natural sciences }\end{array}$ & [122] \\
\hline 2 & $\begin{array}{l}\text { Andrew Carrier } 30 \\
\text { November } \\
2020\end{array}$ & $\begin{array}{l}\text { i)aerial surveys and mapping } \\
\text { ii)agriculture } \\
\text { iii)construction, engineering and mining } \\
\text { iv|) environmental and natural resource management } \\
\text { v)ecological monitoring } \\
\text { vi)climate change research } \\
\text { vii)safety } \\
\text { viii) disaster management } \\
\text { ix)enforcement, energy, and education }\end{array}$ & [121] \\
\hline 3 & $\begin{array}{l}\text { Fatma et al. } \\
\text { Oct } 1,2020\end{array}$ & $\begin{array}{l}\text { i)transportation, road safety, } \\
\text { ii) risk assessment } \\
\text { iii) bridge inspection } \\
\text { iv)barriers, solutions and inspection, air space regulations etc. }\end{array}$ & {$[47]$} \\
\hline 4 & $\begin{array}{l}\text { Derris Ayemba } \\
\text { 4Dec.4,2020 }\end{array}$ & $\begin{array}{l}\text { i)building site evaluation } \\
\text { ii)3 D Scans } \\
\text { iii)supervision and progress checkup } \\
\text { iv)maintenance and damage assessment } \\
\text { v|) health and safety }\end{array}$ & [19] \\
\hline 5 & $\begin{array}{l}\text { Javad et al.15 July } \\
2020\end{array}$ & $\begin{array}{l}\text { i)surface mining } \\
\text { ii)|underground mines } \\
\text { iii) Abandoned mines }\end{array}$ & [25] \\
\hline 6 & $\begin{array}{l}\text { Divya Joshi } 18 \\
\text { Dec,2019 }\end{array}$ & $\begin{array}{l}\text { i)increased efficiency and better productivity } \\
\text { ii), reduce work load and save cost, } \\
\text { iii)improving accuracy, refining service } \\
\text { iv) sole security problems }\end{array}$ & [104] \\
\hline 7 & $\begin{array}{l}\text { Gilles Albeaino et al. } \\
\text { June } 2019\end{array}$ & $\begin{array}{l}\text { i)structural and infrastructure inspection } \\
\text { ii)transportation } \\
\text { iii)culture heritage conservation } \\
\text { iv)city and urban planning , progress monitoring } \\
\text { iv)improve construction safety }\end{array}$ & [23] \\
\hline 8 & $\begin{array}{l}\text { Jin and Mohamad } \\
\text { Oct.2019 }\end{array}$ & $\begin{array}{l}\text { i)UAVs are capable of inspecting the hard-to-reach infrastructure assets. } \\
\text { ii)used as effective tools to survey and map the landscape } \\
\text { iii) guidance to architect to improve building of infrastructure for higher efficiency } \\
\text { (iv) provide reliable and dynamic traffic information }\end{array}$ & [117] \\
\hline 9 & $\begin{array}{l}\text { Matus and Peter } \\
\text { 20January } \\
2019\end{array}$ & $\begin{array}{l}\text { i)increase communication } \\
\text { ii) improve site safety, topographic measurements } \\
\text { ii)aerial photogrammetry, } \\
\text { iii) aerial surveys of bridges, roads, highways } \\
\text { iv)saves project time and cost }\end{array}$ & [34] \\
\hline 10 & $\begin{array}{l}\text { VolkanArslan et al. } \\
\text { October,2019 }\end{array}$ & $\begin{array}{l}\text { i)utilized in mapping applications } \\
\text { ii)environmental change monitoring, } \\
\text { iii)resource exploration } \\
\text { iv)save time and money for contractors } \\
\text { v)military operations and transportation }\end{array}$ & [33] \\
\hline 11 & $\begin{array}{l}\text { William } \\
\text { W.Greenwood } \\
\text { June ,2019 }\end{array}$ & $\begin{array}{l}\text { i)infrastructure component monitoring, } \\
\text { ii)geotechnical engineering } \\
\text { iii)construction management }\end{array}$ & [118] \\
\hline 12 & $\begin{array}{l}\text { Yeting Chen et al. } \\
\text { June } 12,2019\end{array}$ & $\begin{array}{l}\text { i) visualize construction sites } \\
\text { ii)identification of potential safety problems } \\
\text { iii) localize potential safety hazards with aid of BIM } \\
\text { iv) generation of flight routes for safety purpose. }\end{array}$ & [58] \\
\hline
\end{tabular}




\begin{tabular}{|c|c|c|c|}
\hline 13 & $\begin{array}{l}\text { Gaurav et al. } \\
\text { November } \\
2018\end{array}$ & $\begin{array}{l}\text { i)remote sensing and photogrammetry } \\
\text { ii)reduce risk, improve safety } \\
\text { iii)provide guidelines to fly the drone } \\
\text { iv)military applications }\end{array}$ & [54] \\
\hline 14 & $\begin{array}{l}\text { HazimShakhatreh et } \\
\text { al,2018 }\end{array}$ & $\begin{array}{l}\text { i)wireless coverage } \\
\text { ii)actual monitoring, remote sensing } \\
\text { iii)search and rescue, transit } \\
\text { iv)security and surveillance } \\
\text { vi)building construction inspection }\end{array}$ & [115] \\
\hline 15 & $\begin{array}{l}\text { Shi Zhou and Masoud } \\
\text { October ,2018 }\end{array}$ & $\begin{array}{l}\text { i)used in building inspection, damage assessment, site surveying } \\
\text { ii)safety inspection, progress monitoring, building maintenance } \\
\text { iii)cost saving and time efficiency } \\
\text { iv) used in construction cameras, LiDAR and kinet. }\end{array}$ & [28] \\
\hline 16 & $\begin{array}{l}\text { Soroush ,D.and } \\
\text { Mahsa,A.9 July,2018 }\end{array}$ & $\begin{array}{l}\text { i)design and management of projects } \\
\text { ii)improve management of projects } \\
\text { iii)real-time capturing data technology }\end{array}$ & [29] \\
\hline 17 & $\begin{array}{l}\text { Yan Li and Chunlu } \\
\text { Liu } \\
2018\end{array}$ & $\begin{array}{l}\text { i)mapping, surveying, } \\
\text { ii)maintenance and demolition } \\
\text { iii)work safety, saving cost , } \\
\text { iv) help in reducing carbon emission } \\
\text { iv)logistics }\end{array}$ & [6] \\
\hline 18 & $\begin{array}{l}\text { M.Hassanalian And } \\
\text { A. Abdelkefi } \\
\text { April 28,2017 }\end{array}$ & $\begin{array}{l}\text { i) search and rescue operation } \\
\text { ii)environment control measures } \\
\text { iii)goods transport, delivery } \\
\text { iv)space exploration }\end{array}$ & [30] \\
\hline 19 & $\begin{array}{l}\text { Masoud and Behzad } \\
\text { May } 2016\end{array}$ & $\begin{array}{l}\text { i)improve safety performance } \\
\text { ii) reduce potential for human error on construction job sites } \\
\text { iii) efficient communication } \\
\text { iv) actual data creation }\end{array}$ & [111] \\
\hline 20 & $\begin{array}{l}\text { Adam Z.B.A. } \\
\text { January ,2015 }\end{array}$ & $\begin{array}{l}\text { i)area of mapping, tracking work progress } \\
\text { ii)inspection of construction sites } \\
\text { iii) defect location and identification } \\
\text { iv) analyses ageing of infrastructure of highway and bridges. }\end{array}$ & [110] \\
\hline 21 & $\begin{array}{l}\text { Peter Liu et al.April } \\
2014\end{array}$ & $\begin{array}{l}\text { i)risk assessment, transportation } \\
\text { ii) Disaster study } \\
\text { iii)construction management } \\
\text { iv)surveying and mapping } \\
\text { v) flood monitoring and assessment }\end{array}$ & [31] \\
\hline 22 & $\frac{\text { https://www.procrewsc }}{\text { hedule.com,Sept }}$ & $\begin{array}{l}\text { i)remote monitoring and tracking of progress reports } \\
\text { ii)topographic mapping and surveys } \\
\text { iii)automating and equipment tracking } \\
\text { iv)security surveillance } \\
\text { v\}structure inspection and photography } \\
\text { vi)personal safety }\end{array}$ & \\
\hline
\end{tabular}

\section{F. Drone technology, BIM and Construction}

BIM technology is an intelligent 3D modeling tool that supports engineering, architecture and construction professionals to effectively plan, design, modify and manage building and their infrastructure. [1] has explained precisely the utilization of drones in construction for creating accurate BIM models. BIM is a project management technique which allows information to flow across the whole construction process seamlessly. Recently, [71] has conducted a study on applications of DT with BIM to increase productivity and he proved that DT is relatively new industry with more common applications. Consequently, he highlighted the importance of DT, BIM and their integration with another, and lastly concluded that companies can use to further integrate drone with BIM to increase productivity. [124] has described the project of using BIM +UAV technology for efficient and accurate asbuilt data collection. Subsequently, they stated that illustration of the work progress during an infrastructure CP in order to achieve more effective project management, record keeping and delay analysis. Implementation of BIM to improve high rise building performance is reported recently [125].The importance of BIM is growing every methodology models [126] has reviewed the adoption of BIM in the global CI. [114] has extensively described 3 major issues:(i) the current state for BIM and UAS in CPs (ii) use and integration of BIM and UAS towards construction progress monitoring , and (iii) the challenges and opportunities for full automation. [127] supports well various statements laid down .A combination of BIM and UAVs performed better construction safety [58].On the basis of this combination they propose a model that exhibits powerful relationship between the design and construction stages. It allows protection to recognize hazards and develop acceptable mitigation plans [21].Using DT and BIM construction is still worthwhile for building planners for two reasons: (i) drones save time and money and (ii) drones reduce the chance of error. The benefits of DT and BIM construction software are clear in the final outcome. Software run smoothly construction projects and dramatically improves the design of completed buildings

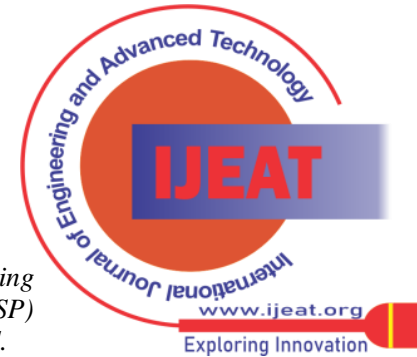


[https://www.hmcarchitects].Drones are offering a new perspective for BIM across the entire construction life-cycle. From as-built to facility management and compliance, drones are quickly providing more data and solve problems once overlooked. Use of drones in construction enhance the BIM workflow is summarized in blog [https://www.thedroneu.com2019].

In adopting new technologies and methods, the human factor is fundamental.[128]has described methodologies and enabled technologies, as well as implemented and planned functionalities of a BIM-based AR application combined with a location-based management system. A new model [129] obtained from drone images can be compared to the BIM model at various construction stages to monitor the construction development. Using BIM and UAVs data created provides useful and smart ways of site supervision and management. Also an improved method involves integration of BIM-laser scanning to quality surveying in construction project life cycle [130]. Donavon Graves [131] has clearly stated 5 ways drones bring value on construction and engineering projects along with some of the top value factors to consider and BIM is one of them. BIM and 3D modeling are important in modern construction. Very recently, [132] has narrated the top stories about the world of drones, asset tracking, productivity tech, construction and more. He later states that as the pandemic continues to alter the way businesses run, construction firms have begun to realize the importance of going digital.

BIM has ability to depict the project development in an open and extremely collaborative environment for CI.[133]has enumerated several complementary angles which include:(i) high client expectations (ii) powerful capacities in technology, (iii) Burgeoning start-up environment, (and (iv)legal documentation. He further expresses his view with top trends that will influence CT trends along with seven futuristic ideas \& examples where BIM is common. Some of the top BIM software solutions available in 2021 include Autodesk BIM 360, Revit, Navisworks, TeklaBIMsight, BIMobject, and BIMx. Use of higher levels of BIM software in construction will increase in 2021.

AEC professionals are integrating BIM and Drone technologies for capturing the real-world environment. Residential and commercial architecture companies use drones and laser scanning technology for capturing data about real-world environments. Combining the power of laser scan technology and BIM software enables competent architecture engineering service providers to analyze data in real time and make the right decisions for meeting client goals [134]. Drones play an important role in providing information for the exact creation of $3 \mathrm{~d}$ digital models. Commercial construction professionals use BIM software to generate accurate $3 \mathrm{D}$ models of buildings from reality-capture data. There are two reasons to use BIM \& Drone by building planners (i) saving time \& money .The benefits of BIM and drones help architectural design firms to complete construction projects and strikingly facilitate the design of completed buildings. Savvy engineers, architects and contractors are now inventing the power of combining BIM with drone technology to get advance [135].However, the key to effectively using BIM is gathering exact data from mapping tools, Google Earth and other resources have become not only an engineering and design, but also a continuously updated data system of the entire building process [https://www.topodrone.com].

\section{G. Challenges and limitations of drone use in CI}

Construction projects are often difficult or dangerous to access for a traditional survey. That means a traditional survey can drag on for days while information is collected and processed. Drones make this process easier, capturing data in 60 to $70 \%$ less time than traditional methods. A number of researchers have quoted challenges in use of drones in construction industry [23],[29],[34],[53],[108],[117].Those challenges include: (i) safety challenges, (ii) project delays and (iii difficulty/danger of mapping and surveying. Use of drones is helps project managers overcome them [136].Drones are very useful tools for any construction project, but they with some challenges [61], [84][101].There are some restrictions to the use of drones in construction, as well as potential complications. Using a company that specializes in DT could help to navigate some of these challenges [https://www.landpoint.net,2019].Some limitations are:(i) drone regulations continue to change,(ii) optimal use of a drone requires the services of a trained professional, (iii)drones have a limited flight time,(iv) drones don't fly well in high wind conditions, and (v) drones may require a specialized data pipeline. However, FFA defines rules and regulation for use of drone in construction and [9] has highlighted certain FAA regulations. Drones remain a powerful tool in the arsenal of any construction project manager irrespective of their limitations.

\section{H. Adoption of recent CT trends and DT in construction project:}

Many Construction technology trends are adopted in construction industry. Modern technology is constantly changing faster than anything else on the planet. [137]the $\mathrm{CI}$ is on the verge of a technological transformation, while the industry is often slow to adopt new tech, IoT devices and other cutting-edge technologies gain traction among construction firms [12],[15][119],[138].Survey drones are at the forefront of this tech adoption trend[61].Across a number of industries, drone technology is being seen as a way to drag decision-making and procedures into 21st century. Commercial and public-sector demands are helping to accelerate advancement in unmanned systems [139].Recently, he quoted that "drones are still a new technology, but the research is spreading its wings". Not only that he had also mentioned that construction and engineering firms were among the earliest adopters of DT. We expect that they will continue to lead the charge for new use cases that leverage faster mobile network, edge computing, photogrammetry, AI, and machine learning. [131] has suggested 5 top value factors to be considered:(i) new insights from drone data not capture before,(ii)added productivity drone workflows,

Published By:
Blue Eyes Intelligence Engineering and Sciences Publication (BEIESP) (C) Copyright: All rights reserved.

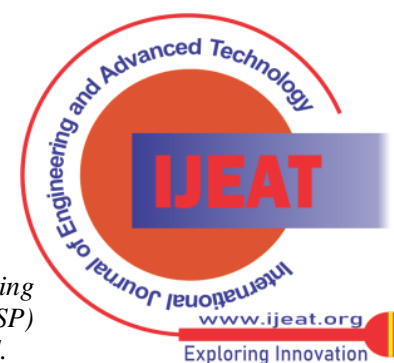


(iii)performing risky jobs with drones for improved worker safety (iv)fewer worker's compensation claims, and(v) faster, richer results with connected drones and 5G. Drones in construction allow contractors a chance to monitor any issue, track progress and develop better plans on-site by providing an unrivalled view of a site at a fraction of the cost. Drones are taking an essential place in the construction process [www.thompsontractor.com], [140] and are increasingly in popularity and functionally. Innovative site managers are frequently finding current applications for DT on construction sites [108]. [141] has summarized top seven CT trends to watch in 2021.Many authors[15],[141] ,[142] have mentioned value of trends namely, software solutions, AI, BIM and digital twins, AR/VR, wearable, modular, offsite and prefab construction, and robotics and drones photography. The importance of each trend extensively and expected to dominate 12 construction trends including drones [143]. AI is a new emerging technology that is on track to revolutionize the CI. Innovative CT enables massive improvements in safety; efficiency and productivity of large-scale construction projects trends described by [16] are almost same as stated in earlier article [133]. Digital technology 2021 is easy to transform the landscape of building and construction. The challenges of 2020 are evident in the emerging CT of 2021. Here [144] are five trends that adapt to new realities and more, coordinating complex sites at safe distances. These trends are: pocket LIDAR, charging up the construction site, eyes on (or in) the site from anywhere, Hardhat Drones, and contact tracing for safety and efficiency. [145] has presented in their review on applications and strategies of green internet of things using UAVs in B5G network. The study of [146] concentrates on the current usage of knowledge of digital technologies in AEC industry to gain an insight in the possible expectations and future trajectory of above said technologies. Thus 2021 are set to be an exciting year for CT towards a safer, more efficient and smarter working environment [ukconnect.com.2021] in CI.

\section{Impact of Corona-19 on construction industry accomplishes drone technology}

The corona virus (Covid-19) pandemic has affected both the local and global economy, in turn, construction industry also [147]. ConnexCore is helping construction companies find ways to leverage DT while protecting the safety for their teams. Drones are providing actionable data, such as $3 \mathrm{D}$, point cloud models, plant health, and asset inventory tracking for construction. [constructech.com,2020] This statement is supported by document laid down by FICCI Committee on drones [ficci.in/5EDoucument,2020].Covid 19 has pushed the construction forward and has displaced unexpected

positive impacts[https://constrible.trembal.com].A report published by Mc Kinsey (2020) states with a great expectation that disruption will shift to next normal. The covid-19 crisis accelerates change that has already been started to occur at scale. Mc Kinsey research suggests that the industry will look radically different five to 10 years.[www.mckinsey.com].[148] has stated the impact of Covid-19 on project performance in CI, while [149] has explained applications of DT in management of disaster and risk associated with Covid-19 pandemic in the built environment . Very recently [150] has focused on future directions of drone routing research during Covid-19 pandemic and findings have emerge out various applications of drones using different models and types. In this year, drones are used to transport Covid vaccine to needy area in Telengana and North East India. During 2021, if the situation persists (existing stage of third wave of Covid19/or persists) it creates new issues for further research on drones/UAVs use in construction.

\section{V.CONCLUSION AND RECOMMENDATION}

The present study comprises application of drones in construction with a brief account of the existing reviews and earlier various sources of literature cited during 20122021.Different types of drones are outlined with functions of each essential component in short. Construction management software promotes will help project managers to manage every aspect to a construction project from initial stages of construction to project delivery. This study examines numerous articles from the last few years and almost 25 applications are given in tabulated form [Table 5]. Usability of drones in construction related industries is also emphasis in addition to prime applications of drones in construction industry [Table 2].The building construction process is discussed from start to finish. Mostly they are design, and planning; procurement, pre-construction; construction, post-construction and close-out. Drones/UAV provides construction stakeholders with expansive, accurate, and precise spatial data. Land surveying, inspection, monitoring any issue, track progress, deploying labor, material waste, annotating maps and images, calculating material types and stockpile volume for inventory and increasing safety. Thirteen articles are accounted to study benefits of drone in construction industry. Increased productivity, accuracy and precision, cost reduction are some benefits. While studying the literature we recorded some limitation and challenges for the use of drones in construction and civil engineering. The common challenges are: (i) safety challenges (ii) project delays, and (iii) difficulty/danger of mapping and surveying. The everimproving capabilities and affordability of drones make it possible to reduce delays, reworks, and safety issues to drive better project performance. Limitations are drone cost, rules and regulation of flight, skill operators, flight time and weather condition. Drone use would lower the costs of projects, increase productivity, create new jobs and add value to the construction sector. Drones can fly in inaccessible and hazardous areas and collect data easily. Drones provide real-time information, leading to significant improvement in surveying accuracy, and boosting overall efficiency in production and communication. Integration of BIM and drone technology plays a role in pre-, during, and post-construction process in terms of digital documentation. It also involve in site surveying, inspection, safety, thermography, modeling, and delivery.

Published By:

Blue Eyes Intelligence Engineering

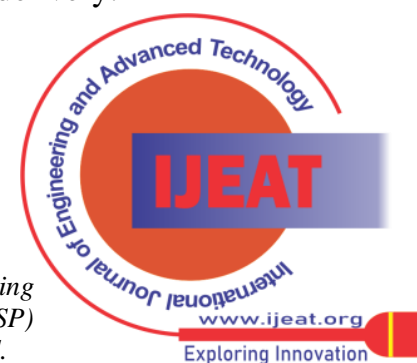


Drone enables massive improvements in number of ways to complete construction project within given time and cost calculated. We have already stated the adoption of more 10 construction technologies with drone technology to improve construction productivity. In future there will be AIsoftware powered drones. The AI will omit the unstructured data captured and will ensure the actionable and structured data, which will give an end to the errors. The amalgamation of cutting-edge technologies (like IoT AI, AR/VR, robot, sensors) definitely help in lower the cost and improve safety with maximizing performance. Nearly all commercial, economic and social activities are suffering from the COVID-19 pandemic. This is also true up to certain extent for construction. Covid-19 pandemic impact on construction industry for 2021, government policies, and global health status will decide economy, development and progress in construction business.

\section{REFERENCES}

1. J.John, Can drones be utilized in construction for creating accurate BIM models? Available: https:// www.e-zigurat.com,2017.

2. R. Ward, Bracing for 2020:past, present, and future of drones in construction. Available: https://www.propelleaero.com,2020.

3. J.Gerardi, The six stages of construction. Available: https://proest.com/construction/process,2021.

4. Hamlet et al., Systematic literature research of the current implementation of Unmanned Aerial System (UAS) in the construction industry: International Journal of Innovative and Exploring Engineering vol.8 IIS,2019.

5. A.Antao, "Drones: A predominant technological innovation in Indian construction", Available: https://inc42.com/resources,2019.

6. Y. Li and C. Liu, Applications of multirotor drone technologies in construction management, Available: https://doi.org/10.1080/15623599.2018.1452101,2018.

7. 7.Big Rentz: 6 Profitable Ways Drones in Construction Are Changing Projects. Available: https://www.bigrentz.com/blog,2018.

8. Admin: How drones are changing the construction industry. Available https://www.constructionplacements.com,2019.

9. J.Camara and Daniel D: Use of drone on construction projects: legal and contractual Consideration. Available htpps://www.american.org/groups/constructionindustry/publications,2019.

10. S.Mansour: How drones will revolutionize the construction industry? Available: https://constructionglobal.com,2020.

11. B.Marr: The top Prop Tech trend:6 technologies disrupting the propery and real-estate industry: https://www.forbes.com,2020

12. G. Patil : Recent aspects on Digitalization of Construction Industry: Construction, Real Estate, Infrastructure \& Project Management. (ISBN No : 978-93-5391-312-0) $23^{\text {rd }}-25^{\text {th }}$ Nov 2018.

13. C. Fadde: 7 Construction Industry trends to watch in 2020, Available: https://interestingengineering.com,2019.

14. J. Goodman: Tech101: Construction drones. Available: https://www.constructiondive.com/news/569796,2020

15. A. Israr et al.: Internet of Things (IoT)-enabled unmanned aerial vehicles for the inspection of construction sites: A vision and future directions. vol. 2021/article/ ID9931112/https: doi.org/10.1155/2021/9931112,2021.

16. L. Stannard: Construction technology to watch 2021. Available: https://www.bigrentz.com,2021.

17. Ivonne: The use of drone technology in architecture, engineering, and construction. Available: https://www.sistaffing.com,2020.

18. R. Elitzer, D.Young: An industrial overview for the standardization of drones in construction, Available: https://www.researchgate.net/publication/329541612,2018.

19. D. Ayema: Utilizing drone technology in construction industry. Available:

20. Daniel Tal and Jon Altsculd: Drone technology in Architecture, engineering and construction: A strategic guide to unmanned aerial vehicle operation and implementation. Kindle Edition: https://www.amazon.in.,dp/1119545889,2021(book). NICMAR -ICCRIP 2018, $3^{\text {rd }}$ International Conference on equipment,2020.

21. Melo et al.: Applicability of UASfor safety inspection on construction sites: Safety Science :98,2017.https://dx.doi.org/10.1016/j.ssci.2017.

22. F.Elghaish et al.: Towards digitalization in the construction Industry with immersive and drone technologies: A critical Review: Smart and sustainable built environment: https://emetald.com,2020.

23. G. Albeaino and M. Gheisari: Trends, benefit, and barriers of UASs in construction industry survey study in the United States: ITcon vol.26:https://www.itcon.org/2021.

24. G. Macrina, Luigi D.P., F. Guerriero, and G. Laporte :Drone-aided routing: A literature review :Transportation Research Part C: Emerging Technologies vol.10,Nov.2020.

25. J. Shahmoradi et al.: A comprehensive review of application of drone technology in the mining industry: Drones 4,(3) MDPI,2020.

26. Robin,K.,Tobia,B. and Lilian,F.: Drones for parcel and passenger transportation :A literature review: Transportation Research Interdisciplinary perspectives. vol. 4. (3), 2020:.https:// doi.org/10.1016/j.trip.2019.

27. G. Singhal and B. Bansod: Unmanned Aerial Vehicle classification, applications and challenges review. Available: https.www.researchgate.net/publication/329422590,2018.

28. S. Zhou and M. Gheisari: Unmanned aerial vehicles in construction: a systematic review :Construction Innovations, vol.8,(4),2018.

29. Soroush ,D. and Mahsa Asnafi:A review on potential applications of unmanned vehicle for construction industry: Sustainable Structure and Material,vol.2,2018.

30. M. Hassanalian, and Abdelkefi,A.: Classifications, applications and challenges of drone: a review: Progress in Aerospace Science 91:www.elsevier.com/locate/paerosci,2017.

31. P. Liu et al.: A review of rotorcraft unmanned Aerial Vehicle (UAV) developments and applications in civil engineering: Smart Structure and System,vol.13,(.6),2014.

32. Gupta et al.: Review of unmanned aircraft system (UAS): International Journal of Advanced Research in Computer Engineering and Technology vol. 2 (4), 2013.

33. VolkanA. ,Serdar ,U. and Aynur,K.: Unmanned Aerial Vehicles in the construction industry: applications and implications. Available https://www.researchgate.net/publication/336890810.Conference paper,2019.

34. M.Tkac and P. Mesaros : Utilizing drone technology in the civil engineering: SSP-Journal of civil engineering vol. 14 issue 1,2019.

35. H. Mahmood, :Use of UAVS (drones) in construction sites "from a war weapon to construction equipment". Available: https://www.researchgate.net/publication/348522650,2021.

36. Z. Dukowitz: Drones in construction: How drones are helping construction companies save money, improve safety conditions, and keep customers happy: https://uavcoach com/drone in construction, 2020.

37. J. Jenson: An introduction to UAV Photogrammetry software. Available: https://uavcoach.com,2019.

38. M. Sheehan: Professional drone mapping software: What are the best options? Available:https://www.commercialuavnews.com,2019.

39. B. Jackson :Top 5 drone mapping software for packages-COPTR Available: https://coptrz.com/top-5-drone- mapping- software,2021.

40. D. Ayema: 2021Utilizing drone technology in construction industry:https://constructionreviewonline.com/machinaryequipment,2020.

41. Norhayati et al.: Unmanned aerial vehicle visual monitoring in construction. Archives: Annals of Romanian Society for cell biology, 3097-3104.Retrived :https://annalsofrscb.ro/index.php/jpurnal/article/view/425,2021.

42. Joseph S.Sanson:Drone use in the construction industry leads to integration into the current civil and construction engineering technology curriculum :Proceeding of the 2019 conference American Society for engineering education ,2019.

43. H.Truman: Using drones for real estate :benefits, use cases and ROfor real `estate. Available : https://www.dartdrones.com .2019

44. K. Piotr et al.: Drones and Possibilities of their Using:Journal of civil and environmental engineering 6:3, 2016.

45. Mark C.Tatum and JunshanLiu:Unmanned aerial vehicles in the construction industry: $3^{\text {rd }}$ Annual International Conference Proceedings: http://www.ascoro.ascweb.org,2017.

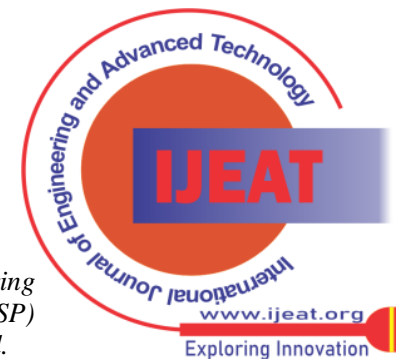


46. F.Riyanto :Real time monitoring study for highway construction using Unmanned Aerial Vehicle (UAV) technology. Internationa Conference on Biospheric Harmony Advanced Research .IOP Conf. Series::earth and environment science 729(2021)012040, 2020.

47. F. Outlay, Hanan Abdullah Mangash and Muhammad Adnan: Application of unmanned aerial (UAV) in road safety, traffic and highway infrastructure management: Recent Advances and Challenges: TranspRes.PartAPract. Nov,141:116-129,2020.

48. R. Moret: The Rise of Drones in Construction. Available: https://www.dronedeploy.com,2018.

49. M. Hader and Stephan Baur: Cargo drones: the future of parcel delivery. Available :https:www.ronaldburge.com,2020.

50. D. Gagne : Predicting the future of drones in the construction industry in 2020 with Richard Lopez Available :https://www.commercialuavnews.com/construction,2020 .

51. R. Staphens et al.: Using drones in planning. Available:https://www.planning.org [report].

52. F. Castellano: Commercial drones are revolutionizing. Available: https://www.toptal.com/finance/market-research-analuysts/drone-

53. Mohd et al : The challenges of drone application in the construction industry :Journal of Technology Management and Business :vol.8 910,2021.

54. Ruiz et al.: Inspection of facades with unmanned aerial vehicle (an explant UAV)|an exploratory study: DOI: https://doi.org/10.21041/ra.v11i1.517,2021.

55. R. Burger: 6 Ways Drones Are Affecting the Construction Industry. Available: https://www.thebalancesmb.com,2019.

56. S. Tasevski, :Drones in Construction Planning, Performance and Contract Close-Out: https://dronebelow.com/2018.

57. E. Ciampa ,Luca,D .V.and Maria,R.P.: Practical issues on the use of drones for construction inspections. J.Phy :Conf.Ser.124901201,2019.

58. Y. Chen et al.: Application of BIM and UAV to safety: https://www.workzonesafety.org/publication:The 7th International Construction Conference Jointly with the Construction Research Congress, 2019.

59. Panjehpour: Drone integrated with BIM: a review current trends in civil and structural engineering. doi:10.33552/CTSE.2019.03.000551,2019.

60. P. Hogan: Drones are improving construction site safety and here's How? Available : www.measure.com,2020.

61. R. Moririson,: Survey drones: rethinking the construction industry. Available: https://www.lotforall.com,2021.

62. A. Davis: Introducing drones into construction for topographic surveys. Available:https://highways.today/2021/03/23/dronestopographic-surveys,2021.

63. Vikshut ,M. and Arjun,J.: Using drone data at each stage of a construction project:https://huviaiair.com.

64. J. Patterson: An aerial view of the future -drones in construction Available: https://www.geospatialworld.net,2018.

65. L. Winters and Mike Sobola: Drones: A vehicle tool for the construction jobsite: https:// connectionexec.com,2021

66. M. Sobola: Drones: A valuable tool for the construction jobsite: https://www.constructionworld.in,2021.

67. A. Huggins: How to deploy drones for construction management , even you are complete beginner

68. Coeckelbergh: Drones, information technology, and distance; mapping the moral epistemology of remote control fighting: Ethics information technology15, 87-98, 2013.

69. PaeNatwilai: Using drones in the construction industry. Available : https://www.geospatialworld.net,2018.

70. Jezekiel R. Bognot et al.: Building construction progress monitoring using unmanned aerial system(UAS),low cost photogrammetry ,and geographic information system (GIS):ISPRS Annals of the photogrammetry remote sensing and spatial information sciences,vol.IV-2,2018.

71. J. Sanchez: Application of drone technology with BIM to increase productivity. https://www.digitalcommons.calpoly.edu,2019.

72. P. Maranpour and A. Mebrabi: Principal and consideration for design of small unmanned aerial vehicles for inspection and survey(final report):https://mme.fiu.edu,2019.

73. D. Giordan et al., The use of unmanned aerial vehicles UAVs for engineering geology applications: Bulletin of Engineering Geology and the Environment 78,2020.

74. R. Ashour et al., Site inspection drone: A solution for inspecting and regulating construction sites:https://www.semanticscholar.org,2016. market, 2017. :https://bim360resources.autodesk.com

75. Track R, And Alice ,G.: Review of UAS applications in the built environment: towards automated building inspection procedures using drones: Automation in Construction, 93:.DOI:10.1016/j.autcon,2018.

76. P. Nousi et al., Embedded UAV real-time visual object detection and tracking: Conference IEEE International Conference on real-time computing and Robotics DOI:10.1109/RCAR47638.2019.9043931,2019.

77. I. Barnes: How drones are changing construction? Available https://www.newcivilengineer.com/2020.

78. Seogdeok et al.: UAV-based automatic generation of high-resolution panorama at a construction site with a focus preprocessing for image stitching: Automation in Construction vol. 84,(12),2017.

79. U. Patel, C. Raichura and J.R.Pitroda :Construction safety management in construction project., International Journal for Research in Applied Science and engineering technology vol.9, issue IV ,2021

80. J. Howard , V. Mand, Christin M.B.: Unmanned aerial vehicles in construction and worker safety :American Journal of Industrial Medicine .vol.6, (1),2017.

81. Tuttas $\mathrm{S}$ et al.: Evaluation of acquisition strategies for image -based construction site monitoring: The international archives of the photography, Remote Sensing and Spatial Information Sciences ,vol XLI-B5,2016.

82. W. Yi and M. Sutrisna: Drone scheduling for construction site surveillance:onlinelibrary.wiley.com/doi.org/10.1111/mice.12593,20 20.

83. V. Kangude ,Rodrigo S. Jamisola and Emmanuel K. Theophilus :A review on drones controlled in real-time.: International Journal of Dynamics and Control 693. https://springer.com.article/10.1007/s400436-020-00737-5,2021

84. Wintra: Drones in construction and infrastructure: chapter 1 : https://wingtra. com, 2018.

85. N. Atwal and S. Henwood: The use of drones in construction projects. Available : https://www.budlehatfield.com,2021.

86. B. Vergouw et al.: Chapter 2 Drones Technology: Types, payload, applications, frequency spectrum issues and future developments cited in book :B. Clusters(ed) :The future of Drone Use, information technology and Law series 27,Doi:10007/978-94-6265-132-6_2 ,2016.

87. A. Lin 2018: Use of drone technology on commercial construction projects. Available : https://digitalcommons.calpoly.edu,2018.

88. O. Maghazel and T. Netland : Drones in manufacturing :exploring opportunities for research and practice: Journal of Manufacturing Technology Management vol.31(6),2020

89. U. Weichenhain : Cutting costs in infrastructure maintenance with UAVs. Available : https://www.rolandberger.com,2019.

90. K. Wiratunga: 5 practical benefits of drone in construction. Available : https://www.e-arc.com,2019.

91. M. Sharma: Major benefits of using drones in construction :https://geospatialworld.net/videos,2019.

92. O. Catterall 23: The benefits and risks o $\mathrm{f}$ using drone in construction: https:www.labewarranty.com.co.uk,2019.

93. J. Rodriguez: How UAVs are being used in construction?:https:www.thebalancesmb.com,2018.

94. R. Mc Portland: Drones in construction https://www.thenbs.com/2021.

95. B. Pienuet: How drones are future-proofing the construction industry. Available: https://www.gim-international.com.2020.

96. S. Fadiya: 5 benefits of drones for construction management Available: https://www.hashmicro.com,2020.

97. B. Pathak: How can drone technology impact the construction industry. Available: https://www.teslaoutsourcingservices.com,2019.

98. M. Danielak: The benefit of employing drones in construction. Available: https:www.cpnstructiondive.com,2018.

99. McCabe et al. : Roles, benefits, and challenges of using UAVs for indoor smart construction applications:researchgate.net/publication/317575171,2017 .

100. Quentin et al.: Potential applications of UAV along the construction's value chain: Procedia Engineering182:www.elsevier.com,2017.

101. P. Natwilal : The benefit of drones in construction industry. Available: https://dronenodes.com

Published By:

Blue Eyes Intelligence Engineering and Sciences Publication (BEIESP)

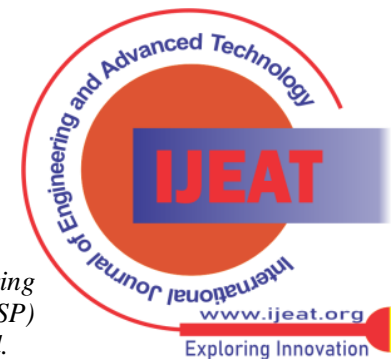


102. S. Herrick: The 3 main categories of drones and their advantages and disadvantages. Available: https://botlink.com,2017.

103. Mario : What are the disadvantages of drones?:https://dronetechplanet.com,2021.

104. D. Joshi : Drone technology uses and applications for Commercial, Industrial and Military drones in 2020 and the future: https://businessinsider.in,2019.

105. C. Pistoris: The impact of emerging technologies on the construction industry. Available : https://deltahedron.co.uk/wp-content/uploads, 2018.

106. D. Saccardo: The impact of emerging technology on the value of construction projects. Research Project:https://bond.edu.au,2020/nz/fies/5115/Saccardo\%20report.pd $\mathrm{f}, 2020$.

107. J. Bird: The drone technology may have on the construction technology. Available : https://pbctoday.co.uk/news,2020.

108. S. Verma: What is the impact of drones in construction? Available https://geospatialworld.net,2020.

109. J. Irizarr, M. Gheisari and Bruce N. Walker : Usability assessment of Information Technology in Construction ITCON, vol. 17,2012.

110. A. Zakwan, B Zainudin :Application of drone in visual inspection for construction project :https://www.core.ac.uk/,2015.

111. M. Gheisan and B. Esmaeili : Unmanned aerial systems for construction safety applications: Conference paper

112. G. Banik : Usability and limitations of UAVs in the US construction industry www.itc.sci.net /2016.

113. I. Mosly: Applications and Issues of Unmanned Aerial Systems in the Construction Industry, International Journal of Construction Engineering and Management,6 (6):2017.

114. Shahab et al.: Application of an interrelated UAS-BIM system for construction progress monitoring, inspection and project management: https://pmsymposium.umd.edu/pm,2017.

115. H. Shakhatreh et al.: Unmanned Aerial Vehicles: A survey on civil applications and key research challenges. Available https://www.arxiv.org/pdf/1805.00881.pdf ,2018.

116. N. Anwar, Muhammad Amir Izhar, F. Najam: Construction Monitoring and Reporting using Drones and Unmanned Aerial Vehicles

(UAVs):https://www.researchgate.net/publication/326264559, 2018.

117. J. Fan and M. Saadeghvaziri : Applications of drones in infrastructures: challenges and opportunities: https://researchgate.net/publication/336262417/Conference paper,2019.

118. W. Greenwood , J. lynch and D. Zekkos: Applications of UAVs in civil infrastructure.: Journal of Infrastructure Systems vol.2( 2), researchgate.net/publication/33060144,2019

119. C. Nigel Preece: An evaluation of the application and challenges in implementing drone technologies in construction project management . Available : https://www.academia.edu/

120. David D.York et al: Potential applications of UAV within the construction industry and challenges limiting implementation: https://ascelibrary.org,2020.

121. A. Carrier: Practical applications of drones in natural resources (where we are and where we are going) Thesis online, 2020.

122. Liza Brown: Drone applications at present and uses in the future: https:// filmora.wondershare.com, 2021.

123. A. Kushal and P. Lochana: Future of construction industry COVID19 and its implication on construction projects and risk assessment: a review:www.preprint.org/doi:10.20944/preprint.o383.v1, 2021.

124. Yiannis et al.: Building Information Modeling (BIM) and Unmanned Aerial Vehicles(UAVs)technologies in infrastructure construction project management and delay and disruption analysis: Proceeding of SPIE-The International Society for Optical Engineering 9535.doi:10.1117/12.2192723,2015.

125. B. Manzoor et al.: Influencing of building information modeling Applied Science ,11,7626,2021.

126. S. Hire, S. Sandhbor, and k. Ruikar : Bibliometric survey for adoption of BIM in construction industry-a safety perspective :Archives of Computational Methods in Engineering https://doi.org/10.10075.May 14,2021

127. Sepehr et al.: The effectiveness of an integrated BIM/UAV model in managing safety on construction sites: International Journal of Occupational Safety and Ergonomics. Available https:doi.org.1080/108035548.1504487,2018.

128. J. Ratajczak et al.: BIM-based and AR application combined with location -based management system for the improvement of the drone technology as safety inspection tools:www.itcon.org ,Journal doi:10.1061/9780784479827.263,2016. 9BIM0implementation in high rise building towards sustainability:

construction

performance:

,9,118;doi:10.3390/buildings9050118(MDPI),2019

Buildings

129. D. Arba: Using UAVs for automated BIM-based construction progress and reporting: PM World JournalVol.IX,IssueVIII-August 2020.

130. Thu Anh Nguyen et al.: Application of BIM 3Dlaser scanning for quality management in construction projects: Advances in Civil Engineering vol. $2020 \quad$ /article 8839923/https://doi.org/10.11555/2020/8839923,2020.

131. D. Graves :5 ways drones bring value on construction and engineering projects: https://www.forconstructionprocs.com,2021.

132. G. Wood: Most read construction stories of March 2021. Available: https://forconstructionpros.com/constructiontechnology/article/21354728, 2021.

133. M. Georgiou: 12 technology trends and ideas for the construction industry in 2021 (with examples) Available : https://www.imaginovation.net,2021.

134. S. Singh : Architectural Engineering and construction planning with BIM Drone, Available : https://www.tejjy.com,2021.

135. A. Shore : How the construction industry is leveraging drones to improve BIM output :https://www.dronegenuity.com.2016

136. L. Myhre : Overcoming the challenges of capturing and using drone Data in construction. Available : https://www.e-arc.com,2019.

137. A. Bouargane: The top 10 technology trends in construction. Available: https://www.bbntimes.com/companies, 2020.

138. G. D'Souza: The scope of drones in the construction sector Available : https://realtyplusmag.com.2020.

139. B. Ewoldsen : Drones are still a new technology, but the research is spreading its wings. Available : www.national acedemics.org,2021.

140. C. Facilitator: The rise of drone in construction: construction. Available : https:// www.constrofacilitator.com ,2019.

141. K. Jones: Top 7 construction technology trends for 2021. Available : https:www.constructionconnect.com, 2021

142. G. Patil: Applications of Artificial Intelligence in Construction Management: International Journal of Research in Engineering, IT \& Social

Sciences,vol.9 https://www.researchgate.net/publication/343722876,2018,2019.

143. T. Ansari : Construction trends that are likely to dominate 2021 Available : https://housing.com/news/2021.

144. Z. Mortice: Construction technology 2021: 5 trends to watch this year. Available : https://redshift.autodesk.com,2021.

145. S.H.Asamhi et al.: Green internet of things using UASs in B5G network: are view of actions and strategies: Ad Hoc Networks ,117,2021.

146. Petra B-S,,Critina C-.L, MikaelJ.and Mattias,R.(2021). The hype factor of digital technologies in AEC. Available : https://www.emerald.com,2021.

147. S. Poikonen and J.Campbell : Future directions in drone routing research. Available : https://onlinelibrary.wiley.com,2021.

148. Muhammad Sami Ur Renan et al. : Impact of Covid-19 on project performance in the UAE construction industry :Journal of Engineering Design and Technology ,June 2021.

149. A. Wahab: Applications of drone technology in the management of disaster and risk associated with COVID- 19 pandemic in the built environment: the Nigerian experience: International Journal of Real Estate Studies 14:SI[2020]73-81.www.utm.my/interest, 2020.

150. I. Zelentsav,B. and Ahmed,A.N.: Covid-19: Key global impacts on the construction Industry and proposed coping strategies.:E35Webof

Web Sources
1. www.cecr.in,2021
2. www.dronepilotgroundschool.com
3. www.safefacilities.com
4. www.ifsec.events/india
5. www.equinoxsdrones.com
6. www.pigeonis.in
7. www.dronebros.com
8. https:biblus.accasoftware.com
9. www.pearsonhigheted.com
10. www advenser com 2017
11. ww.steelcityflightacademy.com
12. www.ukconnect.com.2021
13. www.thomastractor.com conferences,264,05056(2021); https://do.org/10.1051/e3sconf/2021.

Blue Eyes Intelligence Engineering

\section{Available}

C) Copyright: All rights reserved.

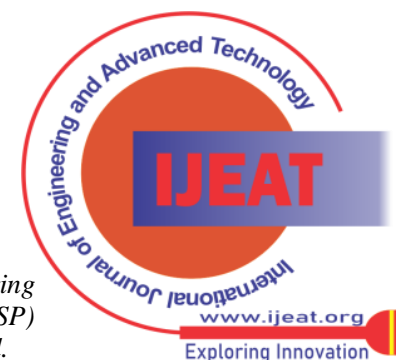


14. https://www.procrewschedule.com,

15. www.c-maanet.org,2016

16. www.designin www.thedrone.eu.com

17. www.topodrone.com, 2019

18. www.landpoint.net,2019

19. www.constructech.com, 2020

20. www.ficci.in/5EDoucument,2020

21. https://constrible.trembal.com,,2021

22. www.mckinsey.com,2021

\section{AUTHOR PROFILE}

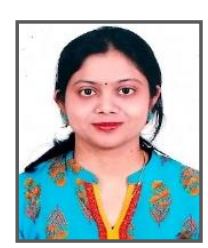

Gayatri Mahajan, completed M. Arch in Construction Management from Allana College of Architecture, Pune in 2015 and Bachelor degree in Architecture from Dr. B.N. College of Architecture, Pune University in 2007. Currently she is working as assistant professor at Allana College of Architecture, Pune. Her academic activities include research in recent trends of Digitalization; like Applications of AI, Machine Learning, BIM, VR, AR, Cloud Computing Technology in Architecture and Construction Management.

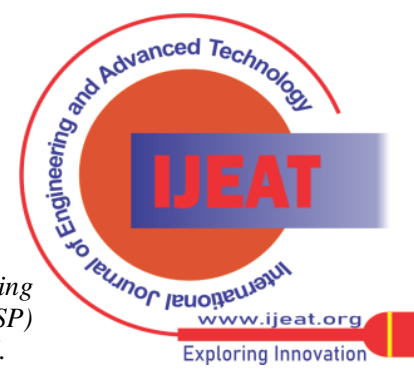

